\title{
MISSION STATEMENT OF SELECTED RETAIL FIRMS: AN ANALYSIS FROM A
}

\section{STRATEGIC MANAGEMENT VIEWPOINT}

\section{Dr. Mamta Brahmbhatt}

\begin{abstract}
:
The objective of this study was to make a comparative analysis of the mission statement of Retail firms, in order to visualize the quality of its mission statement using a Nine Point Scale model given by Fred R. David. Seventeen Retail firms were used as a convenient sample to make analysis in this study. Data needed to make comparative analysis of mission statement were collected from annual reports and websites of these selected companies. This study was limited to the selected Retail firms. Thus, it may lack high Generalizability. Researchers may expand the spectrum of study by investigating other types of sectors to arrive at generalisation.

Acknowledgment: Vision and Mission: Conceptual Roots taken from prescribed textbook titled "Strategic Management Concept and cases by Fred R. David, Prentice Hall". Researcher is thankful to author.
\end{abstract}

\section{Introduction}

The objective of this study was to make a comparative analysis of the mission statement of Retail firms, in order to visualize the quality of its mission statement using a Nine Point Scale model given by Fred R. David. Seventeen Retail firms were used as a convenient sample to make analysis in this study. Data needed to make comparative analysis of mission statement were collected from annual reports and websites of these selected companies. This study was limited to the selected Retail firms. Thus, it may lack high Generalizability. Researchers may expand the spectrum of study by investigating other types of sectors to arrive at generalisation.

\section{Vision and Mission: Conceptual Roots ${ }^{1}$}

Vision is a picture of what the firm wants to be and, in broad terms, what it wants to ultimately achieve. Vision is "big picture" thinking with passion that helps people feel what they are supposed to be doing.

\section{Vision statements:}

\footnotetext{
${ }^{1}$ Vision and Mission: Conceptual Roots taken from textbook titled "Strategic Management Concept and cases by Fred R. David, Prentice Hall".
} 
- reflect a firm's values and aspirations

- are intended to capture the heart and mind of each employee (and, hopefully, many of its other stakeholders)

- tend to be enduring while it is missions can change in light of changing environmental conditions

- tend to be relatively short and concise, easily remembered.

Mission identifies the boundaries of the current business and highlights

- Present products and services

○ Types of customers served

○ Geographic coverage

- Conveys

Who we are, What we do, and Why we are here

Three factors need to be identified for completeness of mission statement.

Customer needs being met (What is being satisfied)

Customer groups or markets being served (Who is being satisfied)

What the organization does (in terms of business approaches, technologies used, and activities performed) to satisfy the target needs of the target customer groups (How customer needs are satisfied)

\section{Difference between Vision and Mission:}

- The mission statement lays out the desire to make a profit, whereas the strategic vision addresses what strategy the company will employ in trying to make a profit.

- a mission statement deals with "where we are headed" whereas a strategic vision provides the critical answer to "how will we get there?"

- a mission deals with what a company is trying to do and a vision concerns what a company ought to do.

- a mission statement typically concerns an enterprise's present business scope and purpose - "who we are, what we do, and why we are here"- - whereas the focus of a strategic vision is on the direction the company is headed and what its future productcustomer-market-technology focus will be.

- a mission is about what to accomplish for shareholders whereas a strategic vision concerns what to accomplish for customers.

\section{Components of Mission Statement}

Customers: Who are the firm's customers? 
Products or services: What are the firm's major products or services?

Markets: Geographically, where does the firm compete?

Technology: Is the firm technologically current?

Concern for survival, growth, and profitability: Is the firm committed to growth and financial soundness?

Philosophy: What are the basic beliefs, values, aspirations, and ethical priorities of the firm?

Self-concept: What is the firm's distinctive competence or major competitive advantage?

Concern for public image: Is the firm responsive to social, community, and environmental concerns?

Concern for employees: Are employees a valuable asset of the firm?

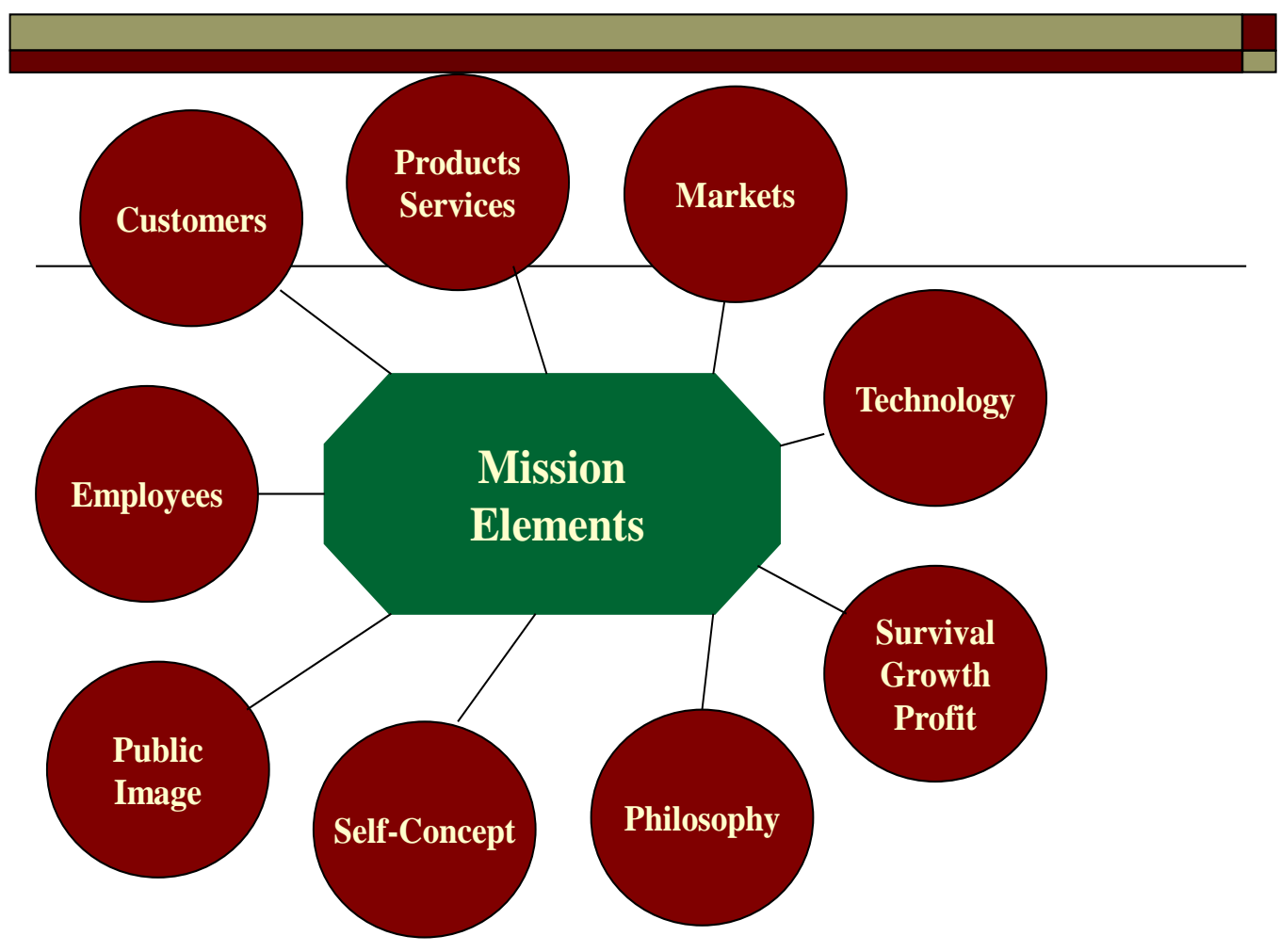

Figure:1 Components of mission statements 


\begin{tabular}{|c|c|}
\hline Company & Mission \\
\hline Titan & $\begin{array}{l}\text { We will do this through a pioneering spirit and a caring, value-driven culture that fosters } \\
\text { innovation drives performance and ensures the highest global standards in everything we do. }\end{array}$ \\
\hline Mcdonald's & $\begin{array}{l}\text { Mission is to be our customers' favorite place and way to eat and drink. Our worldwide } \\
\text { operations are aligned around a global strategy called the Plan to Win, which center on an } \\
\text { exceptional customer experience - People, Products, Place, Price and Promotion. We are } \\
\text { committed to continuously improving our operations and enhancing our customers' experience. }\end{array}$ \\
\hline Coffee Day & $\begin{array}{l}\text { The mission of Coffee Day is to provide authentic, affordable coffee to our customers. And, our } \\
\text { vision is to be present in every space where coffee can be an integral ingredient. We aim to be } \\
\text { one of the top three players, worldwide, in the coffee retail segment. That's a dream we live up } \\
\text { to, and make real everyday... }\end{array}$ \\
\hline Westside & At Westside our mission is to be the most preferred and consistently profitable lifestyle retailer. \\
\hline Barista & $\begin{array}{l}\text { Our mission at Barista Blend is to provide our customers with the most variation in types of } \\
\text { coffee, to provide the best cup of coffee available, and do so in a timely fashion. } \\
\text { Ranging from our classic flavors such as a vanilla cappuccino to our most original chocolate } \\
\text { strawberry banana double dip morning splash, we strive to provide our customers with new and } \\
\text { interesting flavors as well as the classes they love. It is vital to us to have the best ingredients } \\
\text { and provide our customers with their coffee as quickly as possible. }\end{array}$ \\
\hline Shopper's Stop & $\begin{array}{l}\text { "To be a global retailer in India and maintain its No. } 1 \text { position in the Indian market in the } \\
\text { Department Store category." "Nothing but the best". }\end{array}$ \\
\hline Brandfactory & $\begin{array}{l}\text { We help companies to organize, control and improve their visual communication. } \\
\text {-We create solutions so that our customers achieve better control and more efficient handling, } \\
\text { allowing them to develop more value from their visual communication. } \\
\text { - By visual communication, we mean both long-term brand-building communication such as } \\
\text { signage and graphics and more short-term sales promotion communication, in-store or } \\
\text { outdoors. }\end{array}$ \\
\hline Levi strauss & $\begin{array}{l}\text { Mission Statement The Levi Strauss Foundation advances the human rights and well-being of } \\
\text { underserved people touched by our business by taking courageous risks, supporting innovative } \\
\text { community partnerships, and promoting the practice of good corporate citizenship. }\end{array}$ \\
\hline Starbucks & $\begin{array}{l}\text { Our mission: to inspire and nurture the human spirit - one person, one cup and one } \\
\text { neighborhood at a time. }\end{array}$ \\
\hline ITC & $\begin{array}{l}\text { To enhance the wealth generating capability of the enterprise in a globalising environment, } \\
\text { delivering superior and sustainable stakeholder value }\end{array}$ \\
\hline Reliance & "Growth is Life" \\
\hline Walmart & $\begin{array}{l}\text { "We save people money so they can live better." } \\
\text { In addition to this mission statement, the company looks to its founder, Sam Walton for a } \\
\text { company "purpose": } \\
\text { "If we work together, we'll lower the cost of living for everyone...we'll give the world an } \\
\text { opportunity to see what it's like to save and have a better life." }\end{array}$ \\
\hline
\end{tabular}




\begin{tabular}{|c|c|}
\hline Koutans: & $\begin{array}{l}\text { "We aim to lead through innovation \& improve through introspection to serveour } \\
\text { customers and stakeholders equally and become an efficient and low costoperator } \\
\text { with a commitment to quality". } \\
\text { We aim to be world leader yet remain firmly rooted to our local markets }\end{array}$ \\
\hline Aditya birla & To deliver superior value to our customers, shareholders, employees and society at large. \\
\hline Crossword & $\begin{array}{l}\text { Mission Statement They are trying to be dominant retailers and aiming to have a maximum } \\
\text { market share. They focus on life long relationship with the customers. They are trying to create } \\
\text { a friendly, fun, relaxing and rewarding retail environment in urban areas. }\end{array}$ \\
\hline Future group & We will be the trendsetters in evolving delivery formats \\
\hline Guardian & $\begin{array}{l}\text { The Guardian mission is to offer our customers the best and the most reliable pharmacy in India } \\
\text { and build a modern Health and Beauty Retail organization built upon honesty, trust and } \\
\text { commitment using contemporary technology. } \\
\text { As a friendly neighbourhood pharmacy, we will integrate with the community we serve and } \\
\text { treat our customers with respect and dignity. We will always abide by the law and will act as } \\
\text { responsible corporate citizens. } \\
\text { As we expand our stores, we will aim to provide excellent career opportunities in a fast- } \\
\text { growing environment to a diverse group of men and women. We will support these efforts with } \\
\text { innovative thinking and training. } \\
\text { The success we achieve will allow us to reinvest in our future and build long-term financial } \\
\text { security for our employees and our shareholders. }\end{array}$ \\
\hline Provogue & We will make beautiful cloths so our collection will attract people from around the World. \\
\hline
\end{tabular}

Table: 1 Mission statement of selected firms

\begin{tabular}{|c|c|c|c|c|c|c|c|c|c|}
\hline $\begin{array}{l}\text { Name of } \\
\text { the } \\
\text { company }\end{array}$ & Customer & Employees & $\begin{array}{l}\text { Public } \\
\text { Image }\end{array}$ & $\begin{array}{l}\text { Self } \\
\text { concept }\end{array}$ & $\begin{array}{l}\text { Product } \\
\text { Service }\end{array}$ & Market & Technology & $\begin{array}{l}\text { Survival } \\
\text { growth } \\
\text { Profit }\end{array}$ & Philosophy \\
\hline Titan & & & & $\mathrm{Y}$ & & & & & $\mathrm{Y}$ \\
\hline McDonald's & $\mathrm{Y}$ & & & & $\mathrm{Y}$ & $\mathrm{Y}$ & $\mathrm{Y}$ & & \\
\hline Coffee Day & $\mathrm{Y}$ & & & & $\mathrm{Y}$ & & & & \\
\hline Westside & & & & $\mathrm{Y}$ & & & & $\mathrm{Y}$ & \\
\hline Barista & $\mathrm{Y}$ & & & & $\mathrm{Y}$ & & & & \\
\hline $\begin{array}{l}\text { Shopper's } \\
\text { Stop }\end{array}$ & & & $\mathrm{Y}$ & $\mathrm{Y}$ & & $\mathrm{Y}$ & & & \\
\hline $\begin{array}{l}\text { Levis } \\
\text { strauss }\end{array}$ & & & $\mathrm{Y}$ & $\mathrm{Y}$ & & & & & $\mathrm{Y}$ \\
\hline Starbucks & $\mathrm{Y}$ & $\mathrm{Y}$ & $\mathrm{Y}$ & & $\mathrm{Y}$ & & & & \\
\hline ITC & & & & $\mathrm{Y}$ & & & & $\mathrm{Y}$ & \\
\hline $\begin{array}{l}\text { Reliance } \\
\text { Retail }\end{array}$ & & & & & & & & & $\mathrm{Y}$ \\
\hline
\end{tabular}




\begin{tabular}{|l|l|l|l|l|l|l|l|l|l|}
\hline Wal Mart & Y & & & & & & & & Y \\
\hline Koutons & $\mathrm{Y}$ & & $\mathrm{Y}$ & & $\mathrm{Y}$ & & $\mathrm{Y}$ & & \\
\hline $\begin{array}{l}\text { Aditya } \\
\begin{array}{l}\text { Birla Retail } \\
\text { Ltd }\end{array}\end{array}$ & $\mathrm{Y}$ & $\mathrm{Y}$ & $\mathrm{Y}$ & & & & & & \\
\hline Crossword & $\mathrm{Y}$ & & & $\mathrm{Y}$ & & $\mathrm{Y}$ & & & \\
\hline $\begin{array}{l}\text { Future } \\
\text { Retail }\end{array}$ & & & & $\mathrm{Y}$ & & & & & \\
\hline Guardian & $\mathrm{Y}$ & $\mathrm{Y}$ & & $\mathrm{Y}$ & $\mathrm{Y}$ & $\mathrm{Y}$ & & $\mathrm{Y}$ & \\
\hline Provogue & $\mathrm{Y}$ & & $\mathrm{Y}$ & & $\mathrm{Y}$ & & & & \\
\hline & 10 & 3 & 6 & 8 & 7 & 4 & 2 & 3 & 6 \\
\hline
\end{tabular}

Table: 2 Components of mission statements

\begin{tabular}{|l|l|l|}
\hline Name of the company & $\begin{array}{l}\text { Points earned out of } \\
\text { Nine Scale }\end{array}$ & Points earned in \% \\
\hline Titan & 2 & $2 / 9=0.22$ \\
\hline McDonald's & 4 & $4 / 9=0.44$ \\
\hline Coffee Day & 2 & $2 / 9=0.22$ \\
\hline Westside & 2 & $2 / 9=0.22$ \\
\hline Barista & 2 & $2 / 9=0.22$ \\
\hline Shopper's Stop & 3 & $3 / 9=0.33$ \\
\hline Levis strauss & 3 & $3 / 9=0.33$ \\
\hline Starbucks & 4 & $4 / 9=0.44$ \\
\hline ITC & 2 & $2 / 9=0.22$ \\
\hline Reliance Retail & 4 & $4 / 9=0.44$ \\
\hline Wal Mart & 2 & $2 / 9=0.22$ \\
\hline Koutons & 4 & $4 / 9=0.44$ \\
\hline Aditya Birla Retail Ltd & 3 & $3 / 9=0.33$ \\
\hline Crossword & 4 & $4 / 9=0.44$ \\
\hline Future Retail & 1 & $1 / 9=0.11$ \\
\hline Guardian & 7 & $7 / 9=0.77$ \\
\hline Provogue & 3 & $3 / 9=0.33$ \\
\hline
\end{tabular}

Table:3 Points earned out of Nine Scale 


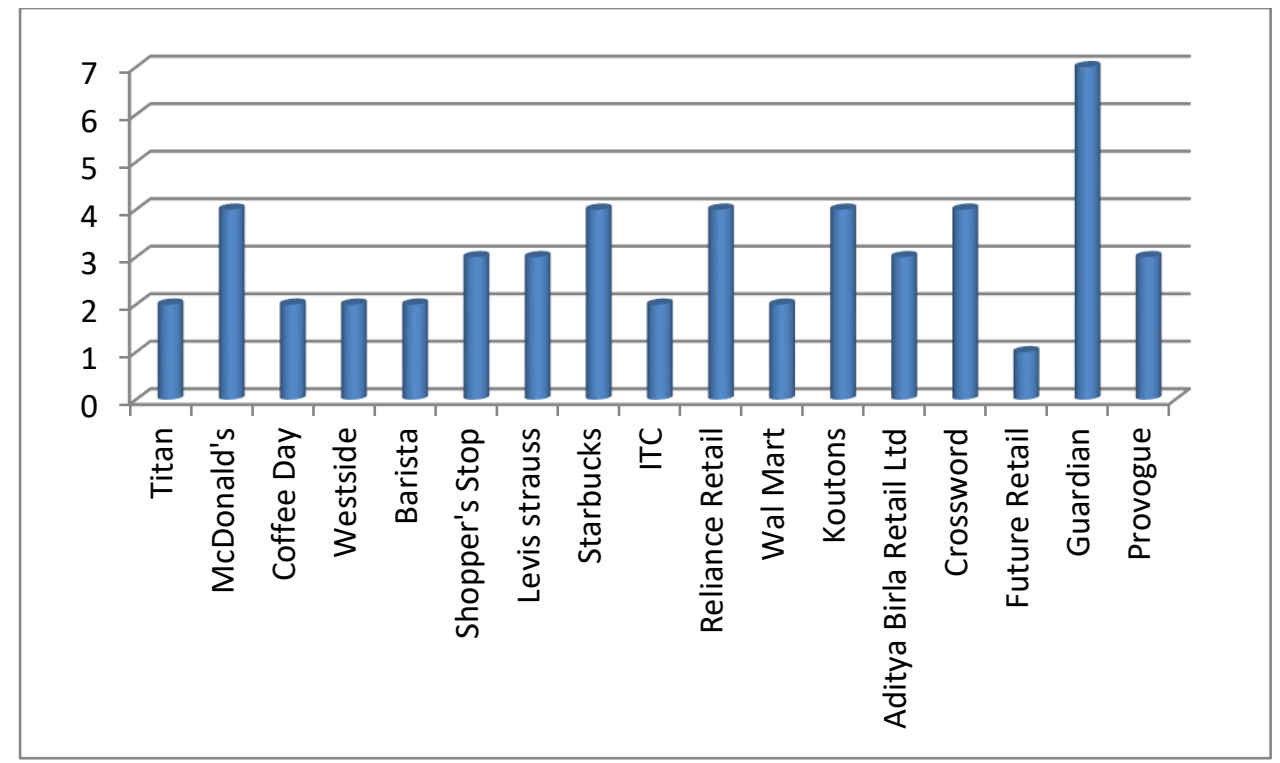

Figure: 2 Points earned out of Nine Scale

\section{Conclusion}

Out of seventeen companies, ten companies' mission statements include the element of concerns for customer, only two companies' mission statements emphasis on technology. Remaining companies' mission statements consist of the elements like Public Image, Self concept, Product Service and philosophy. In Comparative analysis of quality of mission statement using a Nine Point Scale model given by Fred R. David, researcher found that Future Retail scores only one point, which is very low score on nine scale rating. 


\section{References:}

Annual reports of all selected companies

Ahmed, A. (2010). Analysis of the Mission Statement of the Commercial Banks of Bangladesh.

Muhammad Farrukh Moin 1, Ahsan Ali 2, Ali Nawaz Khan (2012), An Analysis of Mission Statement of Pakistani Commercial (Scheduled) banks Using A Nine Points Scale approach of Fred R. David, Interdisciplinary Journal Of Contemporary Research In Business, JUNE 2012 VOL 4, NO 2.

\section{Dr. Mamta Brahmbhatt}

Associate Professor

B .K. School of Business Management, Gujarat University 